\title{
Phosphate Solubilization by Enterobacter cloacae and its Impact on Growth and Yield of Wheat Plants
}

\author{
A. Borham, E. Belal, M. Metwaly and Sh. El-Gremy \\ Agricultural Botany Department (Agricultural Microbiology), Faculty of Agriculture, \\ Kafrelsheikh University, 33516, Kafr El-Sheikh, Egypt.
}

\begin{abstract}
$\mathbf{T}$ HE MOST efficient phosphate solubilizing bacterial strain was isolated from rhizosphere of healthy rice plants and identified as Enterobacter cloacae (B1) based on morphological and biochemical characteristics and 16S r DNA. The optimum phosphate solubilization conditions for $\mathrm{pH}$, temperature and incubation period were obtained at $8,30^{\circ} \mathrm{C}$ and 3 days, respectively. Accordingly, Enterobacter cloacae (B1) was evaluated under field conditions through its impact on growth and yield characteristics of wheat (Triticumaestivum L.) cultivar Masr 1 in comparison with chemical fertilizers (phosphoric acid,calcium super phosphate and NPK). Results of this study showed that, Enterobacter cloacae (B1) effectively increased growth characteristics including plant height $(\mathrm{cm})(9.96 \%)$, fresh weight $(\mathrm{g} / \mathrm{plant})(86.78 \%)$, dry weight (g/plant) $(58.36 \%)$ and flag leaf area $\left(\mathrm{cm}^{2}\right)(53.68 \%)$ and physiological characteristics including chlorophyll pigments content, chl. a, b and total $\left(\mu \mathrm{g} / \mathrm{cm}^{2}\right)(31.91 \%, 35.81 \%$ and $33.33 \%$, respectively)as well as yield characteristics such as spike length $(\mathrm{cm})(13.14 \%)$, spikelets number (13.58 \%), grains number/spike (23.16\%), 1000 kernels weight (g) $(6.49 \%)$, spike weight $(\mathrm{g})(29.37 \%)$, biological weight $\left(\mathrm{g} / \mathrm{m}^{2}\right)(55.92 \%)$ and grains weight $\left(\mathrm{g} / \mathrm{m}^{2}\right)(41.18$ $\%)$ in comparison with control treatment.
\end{abstract}

Keywords: Phosphate solubilizing bacteria, Enterobacter cloacae, Wheat, Chemical fertilizers, Phosphoric acid.

\section{Introduction}

Phosphorus is one of the highly important macro nutrient required by plants. It is a key nutrient for morphological, physiological and biochemical development. Also, it contributes to photosynthesis, energy and sugar production and nucleic acid synthesis (Saber et al., 2005).

Phosphorous is added to cultivated soil in different forms as mineral phosphate fertilizers or organic manure, it is rapidly converted into insoluble complexes such as iron and aluminium phosphate in the acidic soil and calcium phosphate in alkaline or normal soil (Gyaneshwar et al., 2002). This problem is well known in Egyptian soils specially those rich in calcium carbonate (ElGamal, 1996).

To overcome phosphorus deficient problems in soils by safe ways, less expensive costs and friendly environment strategies, Phosphorus Solubilizing Microorganisms (PSMs) have been used to solubilize the precipitated phosphates through converting them into soluble forms,
$\mathrm{H}_{2} \mathrm{PO}^{4-}$ and $\mathrm{HPO}_{4}^{2-}$ that are available to plant (Coutinho et al., 2012). This occurs through principal mechanisms such as acidification of the medium, chelation, ion-exchange reactions and production of various acids (Chung et al., 2005 and Gulati et al., 2010).

The most powerful PSMs that belong to bacteria as Pseudomonas, Enterobacter and Bacillus in addition to fungus such as Penicillium and Aspergillus (Whitelaw, 2000, Wakelin et al., 2004, Yadav et al., 2010 and Xiao et al., 2011). Rhizobium leguminosarumbv. Viciaehave been demonstrated to solubilize inorganic phosphorus by Belal et al. (2013).

Efficiency of PSMs differs significantly with cultural conditions such as $\mathrm{pH}$, temperature and incubation period. Inoculation with PSMs have an important contribution to overall plant $\mathrm{P}$ nutrition and growth, and have increased yields of many crops (Whitelaw, 2000 and Leggett et al., 2001), In particular, under glasshouse conditions (Zaidi et al., 2009 and Khan et al., 2010). More 
importantly, investigations conducted under field level using wheat and maize plants have revealed that PSMs could drastically reduce the usage of chemical or organic fertilizers (Singh and Reddy, 2011).

The present study was designed to isolate, characterize the efficient phosphate solubilizing bacteria and application on wheat plant to improve its growth and yield.

\section{Materials and Methods}

\section{Collection of soil samples}

Soil samples were collected from rhizosphere of healthy plants (rice, maize, cotton, pepper and cucumber) in Kafr Elsheikh Governorate, Egypt stored in polyethylene bags and brought to the laboratory for further studies.

\section{Isolation and screening of Phosphorus Solubilizing Microorganisms}

Ten grams from each soil sample was suspended in a 90-ml sterilized saline solution and serially diluted. The dilutions were plated on Pikovskaya's Agar medium and the plates were incubated at $28{ }^{\circ} \mathrm{C}$ for 3-6 days. The bacterial colonies surrounded with a halo zone were purified then maintained on PVK slants at $4{ }^{\circ} \mathrm{C}$. All bacterial isolates were screened according to the formed halo zone around the colonies. The highest phosphorus solubilizing activity isolate (wider halo zone) were selected for morphological, biochemical and molecular characterization (included DNA extraction and polymerase chain reaction (PCR) at Sigma Scientific Services Co., Giza, Egypt and 16S rDNA gene sequencing technique was conducted using ABI 3730xl DNA sequencer at GATC Company, Germany).

\section{Effect of $\mathrm{pH}$ and temperature on phosphate solubilization efficiency}

Pikovskaya's agar medium (PVK) was adjusted at different $\mathrm{pH}$ values $4.5,5,5.5,6,6.5$, $7,7.5,8,8.5$ and 9 to determine the optimum $\mathrm{pH}$. The selected bacterial strain was spot inoculated at the center Pikovskaya's plate and incubated at $30{ }^{\circ} \mathrm{C}$ for 7 days. Diameter of phosphate solubilization zone was recorded. To determine the optimum temperature, Pikovskaya's agar medium's plates were inoculated with the bacteria then the plates were incubated for 7 days at temperatures $20^{\circ} \mathrm{C}, 30^{\circ} \mathrm{C}$ and $40^{\circ} \mathrm{C}$. Diameter of phosphate solubilisation zone was recorded.
Effect of incubation period on growth and phosphate solubilization efficiency

Pikovskaya's broth medium was used to detect the effect of incubation period on quantative of phosphate solubilization in addition to the growth of the bacterial isolate. $100 \mathrm{ml}$ of the medium was inoculated by $1 \mathrm{ml}\left(10^{9} \mathrm{cfu} / \mathrm{ml}\right)$ of culture of the bacterial strain. a sterilized uninoculated medium was served as a control. The cultures were incubated on a rotatory shaker at $30{ }^{\circ} \mathrm{C}$ and 150 $\mathrm{rpm} / \mathrm{min}$. Every $24 \mathrm{hr}$,solubilized $\mathrm{P}$ was measured spectrophotometrically at $430 \mathrm{~nm}$ according to Subba (1993) and Belalet al. (2013) and also cells number of the bacteria was determined by plating appropriate dilutions of the liquid medium onto nutrient agar medium

Inoculation effect of Enterobacter cloacae (B1) on wheat growth and yield

Field experiment was carried out to evaluate the impact of the selected isolate on growth and yield of wheat (Triticumaestivum L.) cultivar Masr 1. The experiment was carried out in experimental fields of Faculty of Agriculture, Kafrelsheikh University, Egypt during two growing winter successive seasons of 2014/2015 and 2015/2016.

Plots of $1 \mathrm{~m}$ long and $1 \mathrm{~m}$ wide were prepared in the field and hand-sown with $17 \mathrm{~g}$ wheat grains. The wheat grains were inoculated at the time of planting as follows, grains were witted with $10 \%$ sugar syrup, air-dried under shadow and thoroughly mixed with a volume of bacterial suspension previously prepared enough to obtain $10^{8} \mathrm{CFU}$ per gram of grains for half an hour. As per control treatments, plots were sown with uninoculated grains.

The experiment included 9 treatments, T1 (C) control, T2 (P) Phosphorus fertilizer, T3 $(\mathrm{N}+\mathrm{P}+\mathrm{K}), \mathrm{T} 4(\mathrm{~A})$ phosphoric acid, T5 $(\mathrm{A}+\mathrm{P}), \mathrm{T} 6$ (A+NPK), T7 (B1), T8 (B1+P), T9 (B1+NPK).

Chemical fertilizers (NPK) were applied with the respective treatments at the recommended rates as follows: Phosphorus fertilizer dose was applied before sowingas calcium super phosphate $\left(15.5 \% \mathrm{P}_{2} \mathrm{O}_{5}\right)$, Nitrogen fertilizer was added in three doses in the form of urea $(46 \% \mathrm{~N})$ : the first dose $(20 \%)$ at the time of sowing, the $2^{\text {nd }}$ dose $(40 \%)$ before the $1^{\text {st }}$ irrigation and the $3^{\text {rd }}$ dose $(40 \%)$ before the $2^{\text {nd }}$ irrigation and potassium fertilizer dose was applied before the $2^{\text {nd }}$ irrigation in the form of potassium sulphate $\left(48 \% \mathrm{~K}_{2} \mathrm{O}\right)$. 
As per phosphoric acid $85 \%$,it was applied after $1^{\text {st }}$ irrigation (35 days from sowing) at the rate of $3 \mathrm{~cm}^{3} /$ liter. The cultural practices, irrigation and pest control were carried out as commonly used.

The following data were recorded:

- Growth characteristics, plant height $(\mathrm{cm})$, fresh weight / plant (g), dry weight / plant (g): Plants were dried at $70{ }^{\circ} \mathrm{C}$ till constant weight in electric oven and Flag leaf area / plant $\left(\mathrm{cm}^{2}\right)$; measured according to Muller (1991).

- Physiological characteristics, chlorophyll pigments such chlorophyll a, b and total chlorophyll content $\left(\mu \mathrm{g} / \mathrm{cm}^{2}\right)$ were determined in the flag leaf lamina using the spectrophotometer method described by Moran and Porath (1980).

- Yield characteristics, spike length (cm) was measured by the length of the main spike, spikeletsnumber / spike was determined by counting number of fertile spikelets per spike, grains number / spike was computed by counting number of grains of the main spike, 1000-kernel weight (g) was determined as the mean weight of 1000 kernel random sample, spike weight (g) was determined as the weight of the main spike, Biological weight $\left(\mathrm{g} / \mathrm{m}^{2}\right)$ was determined as the weight of harvested plants of $1 \mathrm{sqr}$ meter and grains weight $\left(\mathrm{g} / \mathrm{m}^{2}\right)$ was determined as the weight of harvested grains of 1 sqr meter.

\section{Statistical analysis}

The treatments were distributed in a Randomized Complete Block Design (RCBD). Each treatment was represented by 3 plots as replicates. The collected data were statistically analyzed by CoStatsoftware. Duncan's multiple range tests (DMRT) were used for comparisons among treatments means at 0.05 probability level (Duncan, 1955).

\section{Results and Discussion}

Isolation and screening of phosphorus solubilizing bacteria

Forty - four bacterial isolates were obtained from different plants. The strain B1 showed the highest phosphate solubilization activity (wider halo zone) among all other strains. Identification of Enterobacter cloacae (B1)
using $16 S$ rDNA

The selected bacterial strain (B1) was morphologically and biochemically characterized according to Bergey's manual of Systematic Bacteriology (Krieg and Holt, 1984) as well as using analysis of $16 \mathrm{~S}$ rDNA.

The gene coding of $16 \mathrm{~S}$ rDNA of the strain was amplified by PCR using universal primer. Results in Fig. 1 showed that, 1500 bp DNA fragment was obtained by PCR amplification of $16 \mathrm{~S}$ rDNA gene of the bacterial strain. Then the amplified PCR product has been sequenced, and data of sequence obtained was compared with data base in the Nucleotide Database of National Center for Biotechnology Information (NCBI).

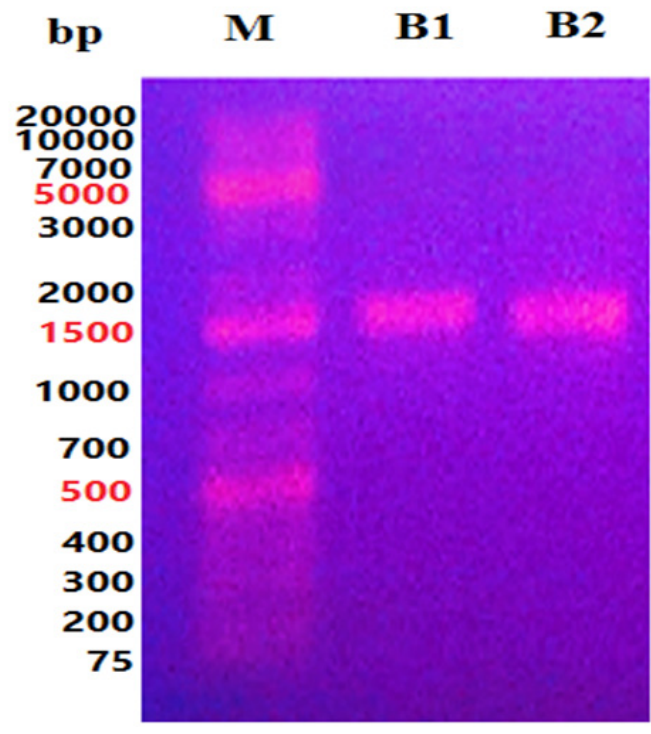

Fig. 1. Agarose gel electrophoresis of purified PCR product B1: Enterobacter cloacae and $\mathrm{M}$ : DNA marker

Phylogenetic analysis of the bacterial strain and related bacterial species according to $16 \mathrm{~S}$ rDNA gene sequence was provided in Fig. 2.This revealed that bacterial strain was most closely related to Enterobacter cloacaestrain ECNH4 (99\%). This result is the same as the finding of Kampfer et al. (2005) who indicated that plant growth promoting bacterial strain D5/23T most closely related to Enterobacter cloacae with $99.0 \%$ and Enterobacter dissolvens with $98.5 \%$ sequence similarity.

J. Sus. Agric .Sci. 43, No.2(2017) 


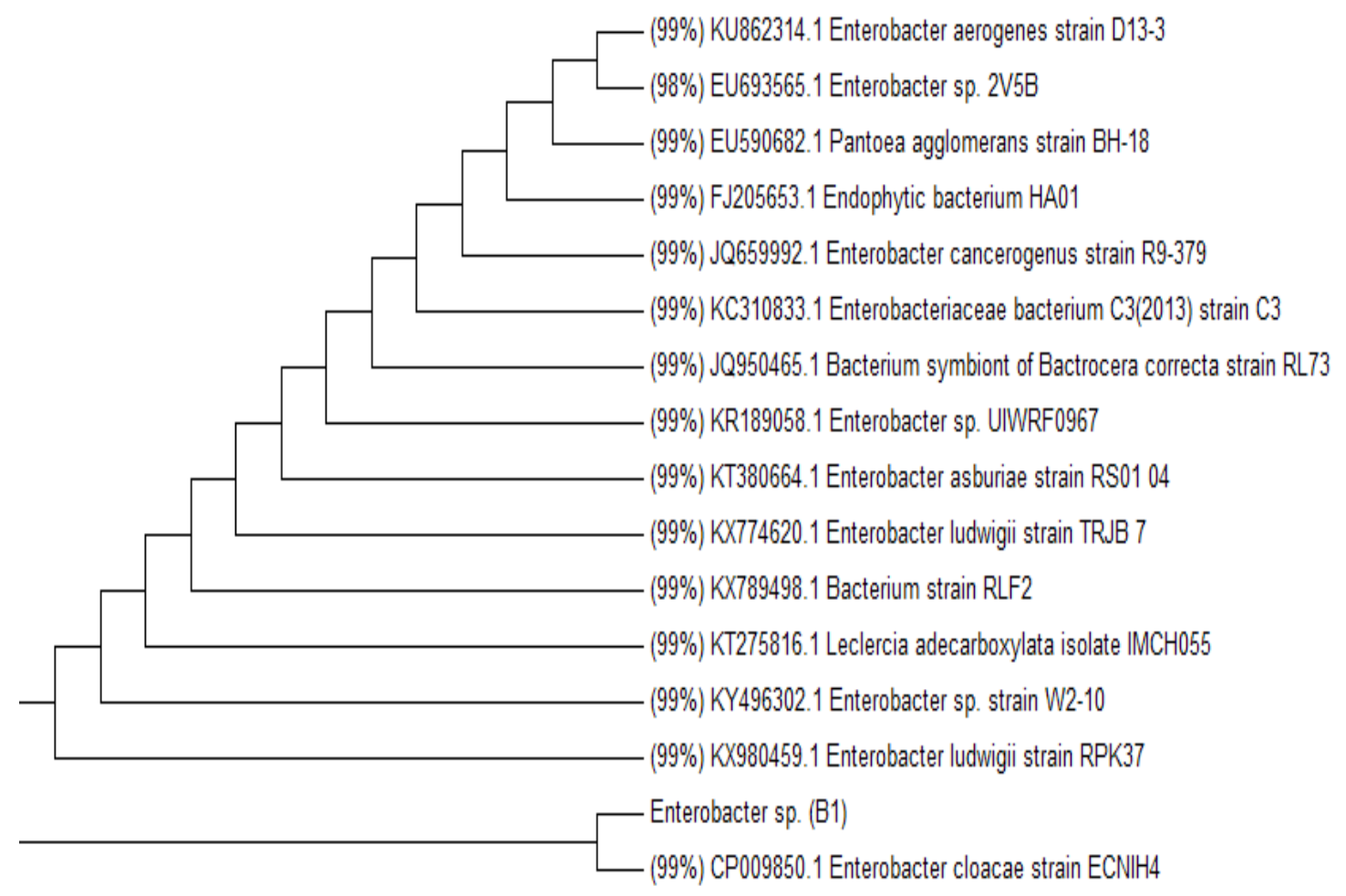

Fig. 2. Phylogenetic tree of 16S rRNA gene sequences of Enterobacter cloacae (B1)

Effect of $\mathrm{pH}$ and temperatureon phosphate solubilization efficiency of Enterobacter cloacae (B1)

Data presented in Fig. 3 and 4 show the influence of $\mathrm{pH}$ and temperature on phosphate solubilization efficiency of E. cloacae (B1) in Pikovskaya's agar medium.

Results showed that E. cloacae (B1) is able to solubilize $\mathrm{P}$ at a wide range of $\mathrm{pH}$ from 4.5 to 9 . and at different temperatures 20,30 and $40{ }^{\circ} \mathrm{C}$. Whereas the optimum $\mathrm{pH}$ and temperature were 8 and $30^{\circ} \mathrm{C}$, respectively.These obtained results are in agreement with Nopparat et al. (2008) who found that the bacterial strain SD02P3218 recorded the highest tricalcium phosphate solubilization at $\mathrm{pH} 8.84$. and temperature $34.7^{\circ} \mathrm{C}$.Previous workers have found that bacteria showed higher phosphate solubilization at pH 7-8 (Seshadri et al., 2002). Also, Mardad et al. (2014) found that, the highest production of orthophosphateby Enterobacter hormaechei was at $\mathrm{pH} 7$ and temperature $30^{\circ} \mathrm{C}$.

Effect of incubation Period on growth and phosphate solubilization efficiency of Enterobacter cloacae (B1)

Data presented in Fig. 5 revealed that, phosphate solubilization has been started when the strain grew on the medium. The maximum phosphate solubilization occurred at the end of logarithmic phase (on the third day). These results were in line with Walpola and Arunakumara (2015) who found that the highest phosphate solubilization of Enterobacter ludwigii and Enterobacter hormaechei was recorded at day 2 and 3 of the incubation, respectively. Also, Jena and Rath (2013) reported that the optimum incubation period of phosphate solubilizing activities was found to be 3 days for five bacterial isolates. phosphate solubilization by Rhizobium leguminosarumbv. Viciae gradually increased up to 7 days on Pikovskaya's Agar medium (Belal et al., 2013).

Inoculation effect of Enterobacter cloacae (B1)on growth characteristicsand yield of wheat plants

Growth characteristics

Data concerning growth characteristics (plant height, fresh and dry weight and flag leaf area) are presented in Table 1. Also, chlorophyll pigments content (chl. a, b and total) is presented in Table 2.

Plant height (cm)

Presented results show that the highest values of plant height were obtained by 


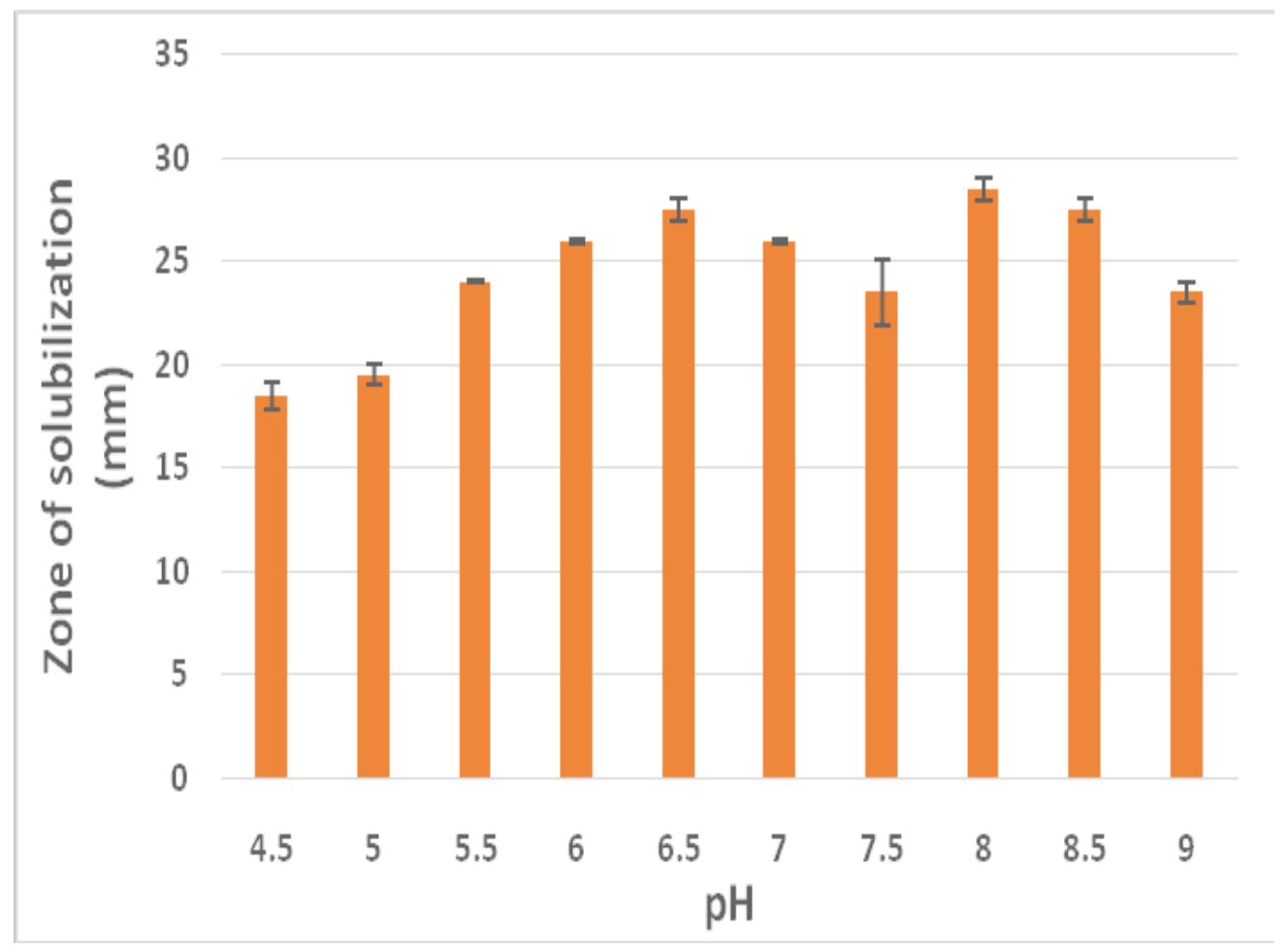

Fig. 3. Effect of pH on phosphate solubilization of Enterobacter cloacae (B1)

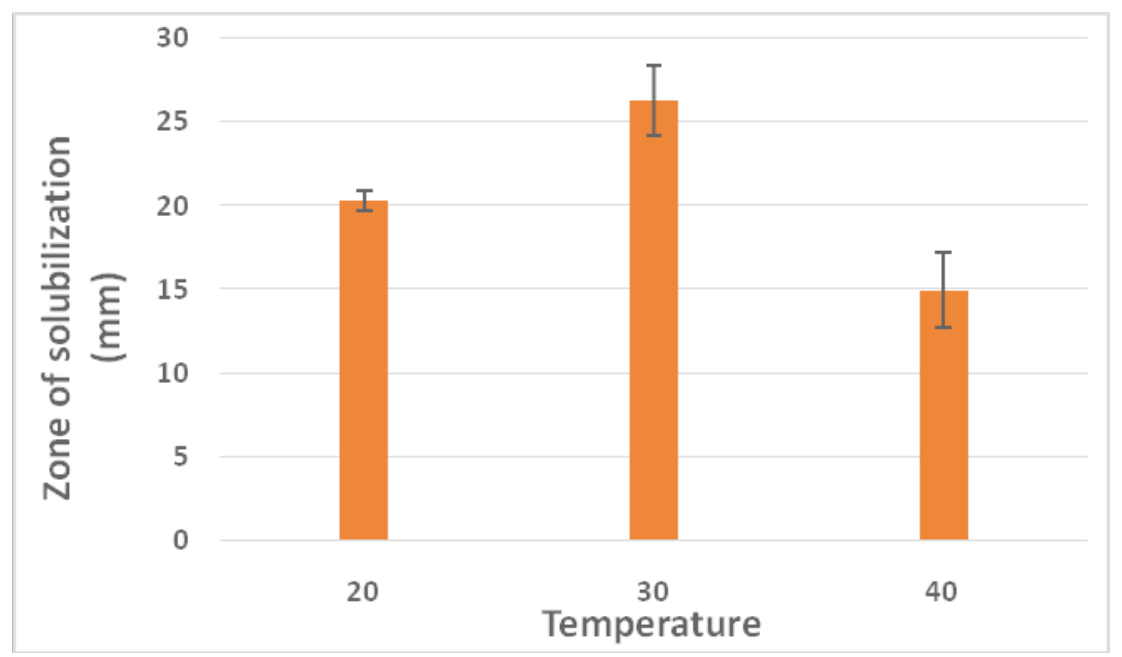

Fig. 4. Effect of temperature on phosphate solubilization Enterobacter cloacae (B1) 


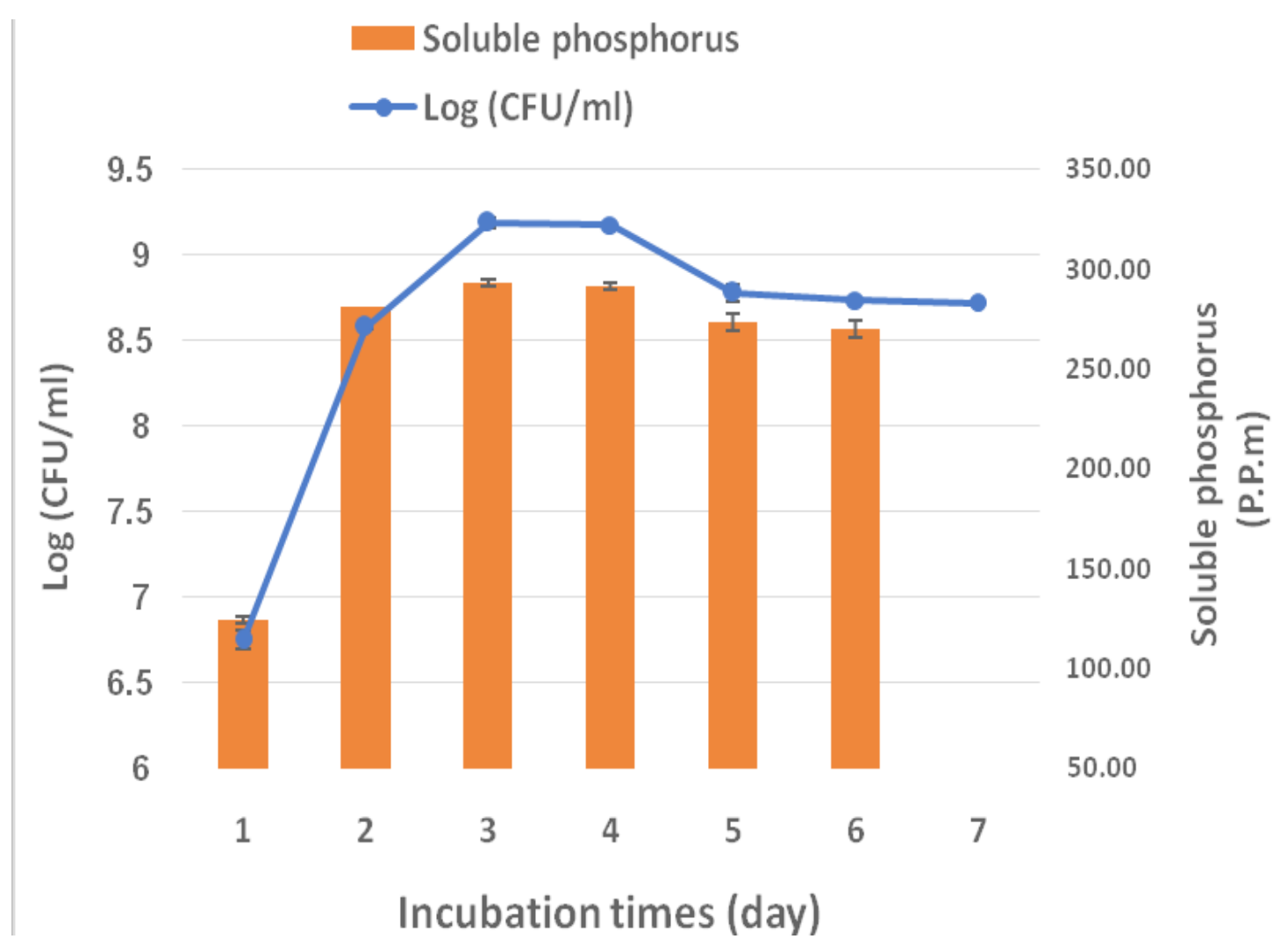

Fig. 5. Effect of incubation period on growth and phosphate solubilization of Enterobacter cloacae (B1).

application of bacterial strain and phosphoric acid in combination with NPK (B1+NPK and $\mathrm{A}+\mathrm{NPK}$ treatments) while the lowest value of plant height was recorded in the control treatment (uninoculated and unfertilized) during the both successive seasons. The treatments $(\mathrm{B} 1+\mathrm{NPK})$ and $(\mathrm{A}+\mathrm{NPK})$ increased plant height insignificantly during the first season and significantly during the second season in comparison with the treatment (NPK) except the second record in the first season of the treatment $(\mathrm{A}+\mathrm{NPK})$ which showed a significant increase. It could be observed that, inoculation of phosphate solubilizing bacteria (B1) increased plant height by about $9.96 \%$ over un-inoculated plants. Also, application of phosphoric acid led to increase in wheat plant height up to $11.53 \%$ over control. The treatment $(\mathrm{B} 1+\mathrm{NPK})$ increased plant height by $12.97 \%$ over (NPK) treatment and the treatment $(\mathrm{A}+\mathrm{NPK})$ increased plant height by $14.92 \%$ over (NPK) treatment. These obtained results are in harmony with those finding by Ramesh et al. (2014) who reported that, plant height increasing in wheat and soybean plants due to inoculation with Enterobacter cloacae subsp. dissolvens MDSR9. Similar increase in growth parameters with the inoculation has been previously reported with inoculation of Enterobacter (Mehnaz et al., 2010, Montanez et al., 2012 and Shoebitz et al., 2009). Kumar et al. (2001) found the combined effect of bacterial inoculants and fertilizer showed maximum increase in plant height.

The increasing in plant growth due to the inoculation with microorganisms having phosphate solubilizing ability may be attributed to auxin production (Gyaneshwar et al., 2002 and Fankem et al., 2008), ACCdeaminase activity (Zafarul- Hye et al., 2007 and Naik et al., 2008), production of organic acids (Fankem et al., 2008) or phosphatases (Abd- Alla, 1994 and Chabot et al., 1996) to solubilize/mineralize $\mathrm{P}$, thereby increasing phosphate nutrition of inoculated plants.

Fresh weight and dry weight ( $\mathrm{g} / \mathrm{plant}$ )

The treatment $(\mathrm{B} 1+\mathrm{NPK})$ recorded the highest mean values of fresh and dry weight during 


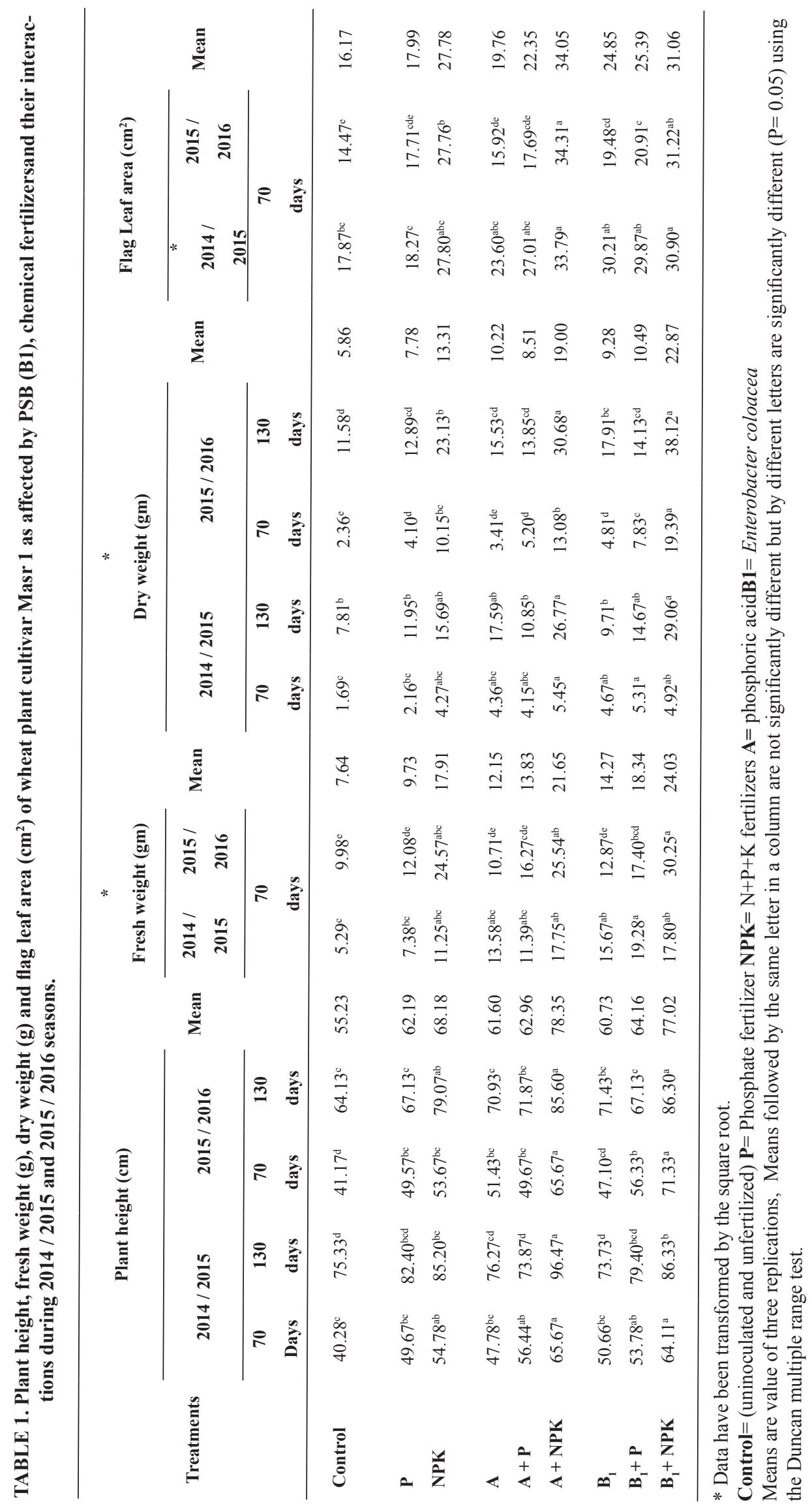




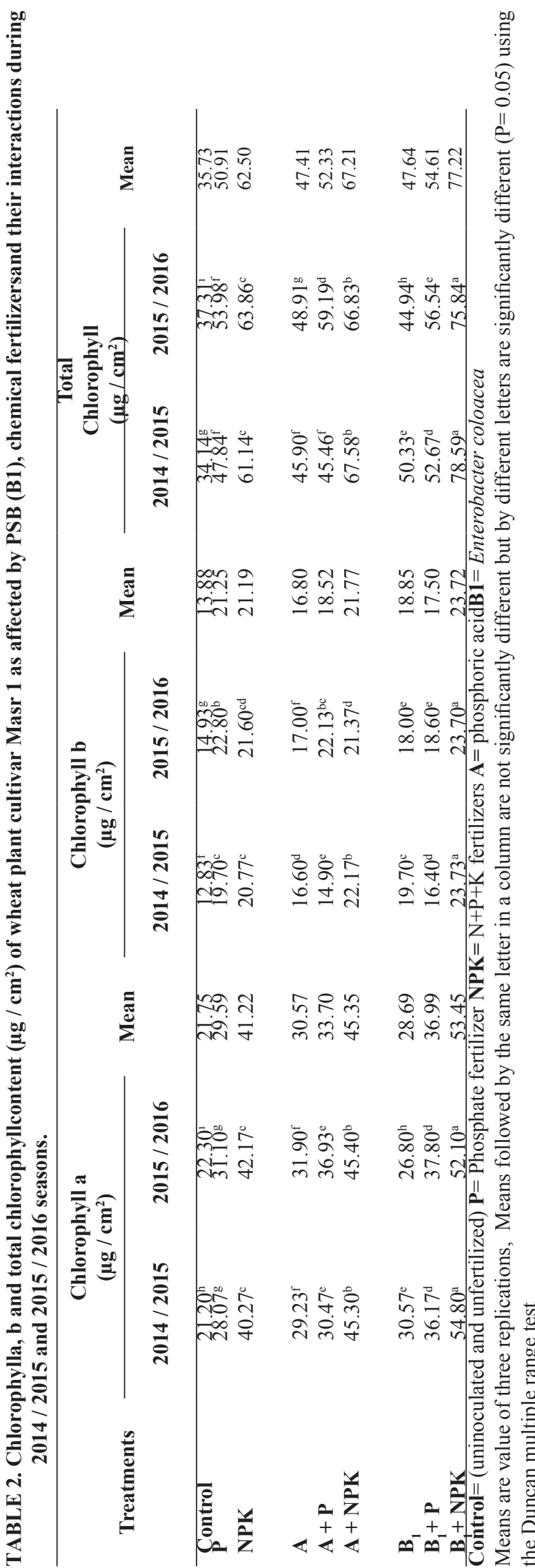

the both seasons. While the lowest values were recorded by the control treatment (uninoculated and unfertilized) during the both seasons. The treatment $(\mathrm{B} 1+\mathrm{NPK})$ increased insignificantly fresh weight during both seasons and increased dry weight insignificantly during the first season and significantly during the second season in comparison with (NPK) treatment. The treatment (B1) significantly increased fresh weight and dry weight (first record) during the first season whereas during the second season increased insignificantly fresh weight and significantly dry weight in comparison with its respective control (uninoculated and unfertilized).

Generally, the treatment (B1) increased fresh weight and dry weight by $86.78 \%$ and 58.36 $\%$, respectively over control and the treatment (B1+NPK) increased fresh weight and dry weight by $34.17 \%$ and $71.83 \%$, respectively over (NPK) treatment.These findings are almost similar to those of Schoebitz et al. (2007) who found a statistically significant increase in shoot fresh weight evident in plants inoculated with Enterobacter ludwigii. Ramesh et al. (2014) also reported that inoculation with Enterobacter cloacae subsp. dissolvens MDSR9 led to an increase in dry weight in both soybean and wheat crops over un-inoculated control.All quantitative plant traits showed significant increase in response to chemical fertilizer treatments, this response was further substantiated with bacterial inoculation (Kumar et al., 2001).

\section{Flag leaf area $\left(\mathrm{cm}^{2}\right)$}

Based on data in Table 1, the highest values of flag leaf area $\left(\mathrm{cm}^{2}\right)$ were obtained by the treatments $(\mathrm{A}+\mathrm{NPK})$ and $(\mathrm{B} 1+\mathrm{NPK})$ while the lowest value was obtained in control treatment (uninoculated and unfertilized) during the both seasons. The treatment $(\mathrm{B} 1+\mathrm{NPK})$ insignificantly increased flag leaf area $\left(\mathrm{cm}^{2}\right)$ in comparison with (NPK) treatment during the both seasons. The treatment (B1) increased flag leaf area $\left(\mathrm{cm}^{2}\right)$ insignificantly during the first season and significantly during the second season in comparison with its respective control. The treatment (B1) increased flag leaf area $\left(\mathrm{cm}^{2}\right)$ by $53.68 \%$ over control and the treatment (B1+NPK) increased flag leaf area $\left(\mathrm{cm}^{2}\right)$ by 11.81 $\%$ over (NPK) treatment.

These obtained results are similar to other investigators (Panhwar et al., 2011 and AlShamma and Al-Shahwany, 2014). 


\section{Physiological characteristics (chlorophyll pigments $\left(\mu \mathrm{g} / \mathrm{cm}^{2}\right)$}

Data presented in Table 2 cleared that, the treatment $(\mathrm{B} 1+\mathrm{NPK})$ recorded the highest values of chlorophyll pigments (chl. a, b and total) content $\left(\mu \mathrm{g} / \mathrm{cm}^{2}\right)$ during the both seasons except chl. $b$ of the second season. $(\mathrm{B} 1+\mathrm{NPK})$ treatment significantly increased chlorophyll pigments (chl. $\mathrm{a}, \mathrm{b}$ and total) content $\left(\mu \mathrm{g} / \mathrm{cm}^{2}\right)$ in comparison with (NPK and $\mathrm{A}+\mathrm{NPK}$ ) treatmentsduring the both seasons. On the other hand, the treatment (B1) significantly increased chlorophyll pigments (chl. $\mathrm{a}, \mathrm{b}$ and total $)$ content $\left(\mu \mathrm{g} / \mathrm{cm}^{2}\right)$ in comparison with untreated control which recorded the lowest value. The treatment (B1) increased chl. a, b and total by $31.91 \%, 35.81 \%$ and $33.33 \%$, respectively over control and the treatment (B1+NPK) increased chl. a, b and total by $29.67 \%, 11.94 \%$ and 23.55 , respectively \% over (NPK) treatment.These findings are similar to those of Panhwar et al. (2011) who found that PSB inoculated treatments on aerobic rice demonstrated a significant increase in chlorophyll content and leaf photosynthesis compared to non-inoculated treatments. Mehrvarz et al. (2008) also reported similar results with mycorrhiza along with PSB (Pseudomonas putida) which showed an increase in leaf chlorophyll content in barley. Al-Shamma and Al-Shahwany (2014) reported that the combination of biofertilizer (A. chroococcum, A. brasilense and P. fluorescens) and $100 \%$ NP significantly affected flag leaf chlorophyll content (55.05 SPAD). Application of Azotobacter chrocooccum (E1) and Pseudomonas sp. (E2) strains individually increased chlorophyll pigment contents $\left(\mu \mathrm{g} / \mathrm{cm}^{2}\right)$ for two wheat cultivars compared with untreated plant (El-Afry et al., 2012).

\section{Yield and its components}

Data concerning yield characteristics (spike length, spikelets number, grains number, 1000 kernels weight and spike weight) are presented in Table 3. As well, biological and grains yield are presented in Table 4.

\section{Spike length (cm) and spikelets number}

Data in Table 3 revealed that, the treatment $(\mathrm{A}+\mathrm{NPK})$ gavet he highest value of spike length (cm) and spikelets number during the first season and increased insignificantly spike length and spikelets number compared to (B1+NPK) and (NPK) treatments during the first season. On the contrary,during the second season the treatment
(B1+NPK) was the highest and increased significantly spike length and spikelets number compared to $(\mathrm{A}+\mathrm{NPK})$ and $(\mathrm{NPK})$ treatments. The treatment (B1) increased significantly spike length and spikelets number during the both seasons in comparison with uninoculated and unfertilized treatment which recorded the lowest value.

The treatment (B1) increased spike length and spikelets number by $13.14 \%$ and 13.58 $\%$, respectively over control and the treatment (B1+NPK) increased spike length and spikelets number by $6.31 \%$ and $5.69 \%$, respectively over (NPK) treatment.

These obtained results are in line with similar previous findings (Khalid et al., 1997, Hilaliet al., 2000 and Afzal \& Bano, 2008), who reported an increase in spikelets per spike and spike length of various crop plants by microbial inoculation. Also, Kumar et al. (2001) reported the combined effect of bacterial inoculants and fertilizer showed maximum increase in spike length $(11.3 \%)$ and spikelet spike ${ }^{-1}$ $(11.1 \%)$ in wheat crop. The agronomic traits and yield have been increased when plants inoculated with bio-fertilizers combined with mineral fertilizers, and that is because of the application of bio-fertilizers which may be attributed to their role by enhancing plant growth due to the availability of different nutrients including $\mathrm{N}, \mathrm{P}$ and $\mathrm{K}$ in addition to several micronutrients (Al-Shamma and AlShahwany, 2014).

\section{Grains number / spike}

Concerning grains number, the obtained results exhibited that, the highest value during the first season was recorded by the treatment $(\mathrm{A}+\mathrm{NPK})$ and increased insignificantly grains number per spike in comparison with (B1+NPK) and (NPK) treatments. Whereas, during the second season the treatment $(\mathrm{B} 1+\mathrm{NPK})$ was the highest value and increased significantly grains number in comparison with (A+NPK and NPK) treatments. The treatment (B1) increased grains number insignificantly during the first season and significantly during the second season in comparison with control which recorded the lowest value in the both seasons. The treatment (B1) increased grains number by $23.16 \%$ over control and the treatment $(\mathrm{B} 1+\mathrm{NPK})$ increased grains number by $7.92 \%$ over (NPK) treatment.

These obtained results are in agreement with many other investigators (Kumar et al., 2001, Minaxi et al., 2013 and Al-Shamma \& J. Sus. Agric .Sci. 43, No.2(2017) 
Al-Shahwany, 2014). In contrast, Bulut (2013) reported that the highest number of kernels per spike was obtained from $\mathrm{N}$ and $\mathrm{N}+\mathrm{P}$ treatments while the lowest values were obtained in treatments of bacteria and control. Fertilization improves nutrition and increases the number of fertile spikelets and flowers, and consequently increases the number of kernels per spike (Singh and Prasad, 2011).

\section{0 kernels weight (g)}

Based on data exhibited during the first season, none of the treatments had any influence on 1000 kernels weight of wheat as compared to control. These findings are almost similar to those of Afzal et al. (2005) who found that, there is no influence of treatments on spike length, total and fertile spikelets per spike and grains per spike of wheat as compared to control.

Whereas during the second season (A+NPK) treatment gave the highest one followed by the treatment (B1+NPK) which increased insignificantly 1000 kernels weight in comparison with (NPK) treatment. The treatment (B1) increased significantly 1000 kernels weight in comparison with control which recorded the lowest value. The treatment (B1) increased 1000 kernels weight by $6.49 \%$ over control. The obtained results are similar to the findings of Kumar et al. (2001) and Minaxi (2013) who reported 1000 grain weight increasing over control due to the inoculation of phosphate solubilizing bacteria. Also, Al-Shamma and Al-Shahwany (2014) showed that, the combination of biofertilizer and $100 \%$ NP significantly affected average weight of 1000 grains. similarly, the highest values of 1000-kernel weight were observed in single $\mathrm{N}$ and bacteria treatments (Bulut, 2013).

\section{Spike weight (g)}

Data regarding spike weight presented in Table 3 showed that, the treatment (B1+NPK) recorded the highest value and increased significantly spike weight in comparison with (NPK) treatment. Also, the treatment (B1) increased significantly spike weight $(\mathrm{g})$ in comparison with control treatment which recorded the lowest value. The treatment (B1) increased spike weight by $29.37 \%$ over control and the treatment (B1+NPK) increased spike weight by $12.22 \%$ over (NPK) treatment. These obtained results are similar to the findings of Minaxi et al. (2013) who reported maximum increase in spike weight evident in the treatment having combination of 2 rhizobacterial strains along with arbuscular mycorrhizal and tricalcium phosphate at the time of harvesting.

\section{Biological and grains weight $\left(\mathrm{g} / \mathrm{m}^{2}\right)$}

Biological and grains weight $(\mathrm{g})$ of wheat cultivar Masr 1 were presented in Table 4. The obtained results showed that, the treatment $(\mathrm{A}+\mathrm{NPK})$ gave the highest values of biological and grains weight $(\mathrm{g})$ and the lowest value was recorded by control treatment during the both seasons. the treatment $(\mathrm{B} 1+\mathrm{NPK})$ increased insignificantly biological and grains weight in comparison with (NPK) treatment during the both seasons. Also, the treatments $(\mathrm{B} 1+\mathrm{P})$ and (B1) increased biological and grains weight (g) insignificantly during the first season and significantly during the second season in comparison with their respective controls ( $\mathrm{P}$ and control). The treatment (B1) increased biological and grains weight by $55.92 \%$ and $41.18 \%$, respectively over control and the treatment (B1+NPK) increased biological and grains weight by $7.57 \%$ and $4.46 \%$, respectively over (NPK) treatment.These results confirmed with the findings of Afzal and Bano (2008) whose reported that inoculation of phosphorus $(\mathrm{P})$ solubilizing bacteria with fertilizer $\left(\mathrm{P}_{2} \mathrm{O}_{5}\right)$ was better than only $\mathrm{P}$ fertilizer for improving grain yield of wheat. Similarity, Vahed et al. (2012) indicated that PSB and Phosphate chemical fertilizer had a significant influence on grain yield, biological yield and grain phosphorus uptake. The yield components (biological and grains yield) have been increased when plants inoculated with bio-fertilizers combined with mineral fertilizers, and that because the application of bio-fertilizers which may be attributed to their role by enhancing plant growth due to the availability of different nutrients including $\mathrm{N}, \mathrm{P}$ and $\mathrm{K}$ in addition to several micronutrients (Al-Shamma and Al-Shahwany, 2014).

Concerning phosphoric acid, application of $\mathrm{P}$ as phosphoric acid (fluid $\mathrm{P}$ source) produced significantly higher wheat grain yield and grain weight over commercial phosphate fertilisers, i.e. diammonium phosphate (DAP) and triple superphosphate (TSP) (Akhtar et al., 2016).

Some Australian scientists confirmed the superiority of fluid P fertilizers over the granular P-fertilizer and produced $31 \%$ more wheat yield 

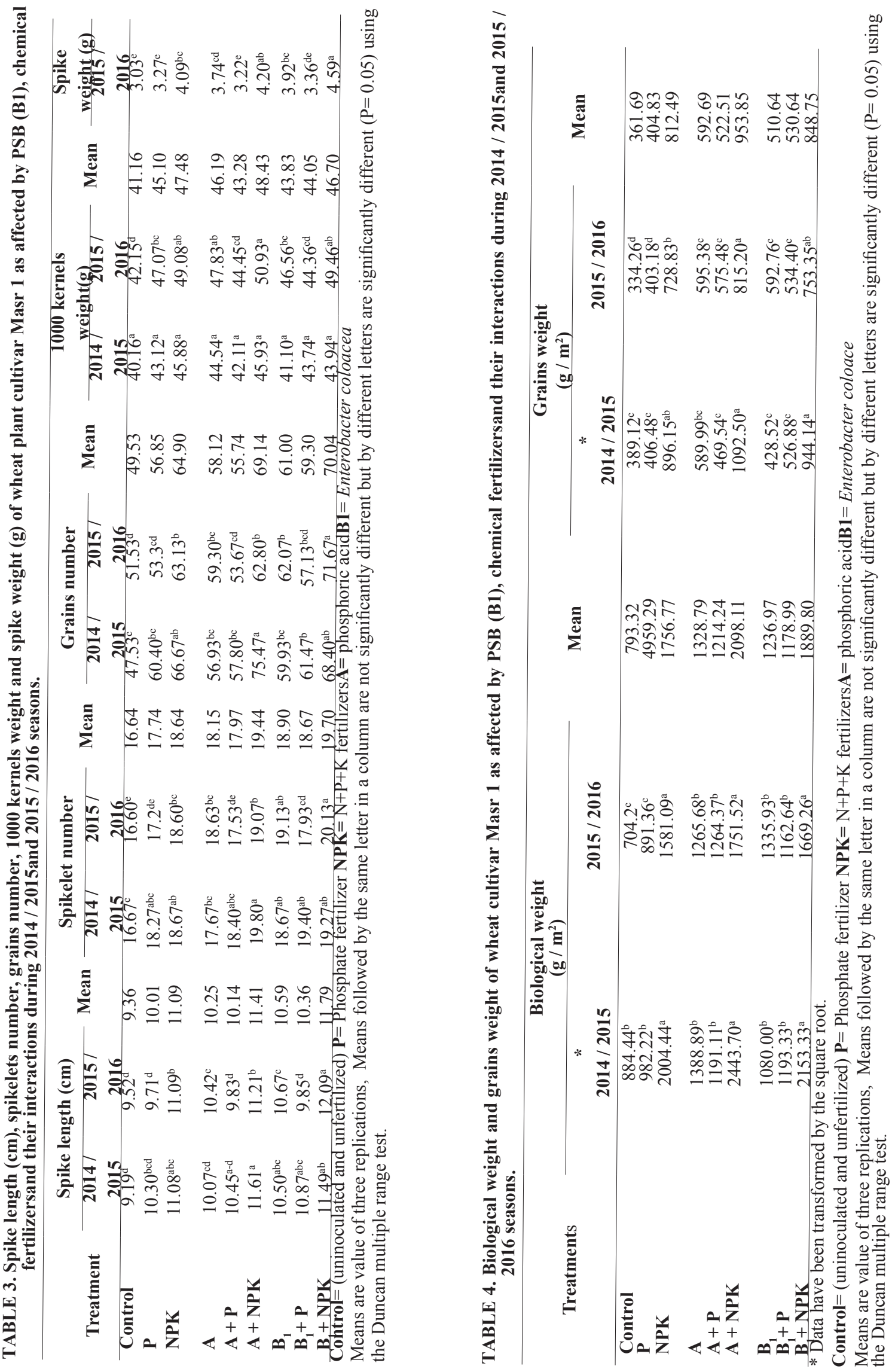

J. Sus. Agric .Sci. 43, No.2(2017) 
using fluid P-fertilizers as compared to granular ones (Holloway et al., 2001).

Holloway et al. (2001) also found superiority of phosphoric acid over commercial $\mathrm{P}$ fertilizers while evaluating different solid versus liquid $\mathrm{P}$ fertilizers. The superiority of PA over DAP and TSP for producing grain yield may be attributed to its ability to maintain higher solution $\mathrm{P}$ in soil as found by Naeem and Akhter (2013). Moreover, PA induced reduction in nitrogen loss as ammonia volatilization (Akhtar and Naeem, 2012) could be another factor making it more efficient than the solid fertilizers.

\section{References}

Abd-Alla, M.H. (1994) Phosphatases and the utilization of organic $\mathrm{P}$ by Rhizobium leguminosarum biovarviceae. Letter in Applied Microbiology, 18, 294-296.

Afzal, A. and A. Bano, (2008) Rhizobium and phosphate solubilizing bacteria improve the yield and phosphorus uptake in wheat (Triticumaestivum). Int. J. Agri. Biol., 10, 85-88.

Afzal, A., Ashraf, M., Asad, S.A. and Farooq, M. (2005) Effect of phosphate solubilizing microorganisms on phosphorus uptake, yield and yield traits of wheat (Triticumaestivum L.) in rainfed area. Int. J. Agri. Biol., 7 (2), 207-209.

Akhtar, M. and Naeem, A. (2012) Reduction in ammonia loss by applying urea in combination with phosphate sources. Comm. Soil. Sci. Plant Anal., 43, 2043-2049.

Akhtar, M., Yaqub, M., Naeem, A., Ashraf, M. and Hernandez, V. E. (2016) Improving phosphorus uptake and wheat productivity by phosphoric acid application in alkaline calcareous soils. J. Sci. Food Agric., 96, 3701-3707.

Ali, Y. and Aslam, Z. (2005) Use of environmental friendly fertilizers in saline and saline sodic soils. Int. J. Environ. Sci. Tech. 1 (4), 97-98.

Al-Shamma U.H. and Al-Shahwany, A.W. (2014) Effect of mineral and bio-fertilizer application on growth and yield of wheat Triticumaestivum L. Iraqi Journal of Science, 55 (4A), 1484-1495.

Belal, E.B., Hassan, M.M. and El-Ramady, H.R. (2013) Phylogenetic and characterization of salt-tolerant rhizobial strain nodulatingfaba bean plants. Afr. J. Biotechnol, 12 (27), 4324-4337.

Bhardwaj, S., Bhattacharya, S. and Das, A. (2012)
Phosphate solubilizing activity of a mangrove isolate of Streptomyces badius from Muthupettai Mangrove, Tamil Nadu, India. Journal of Chemical, Biological and Physical Sciences, 2 (2), 868-876.

Bulut, S. (2013) Evaluation of yield and quality parameters of phosphorous-solubilizing and $\mathrm{N}$-fixing bacteria inoculated in wheat (Triticumaestivum L.). Turk. J. Agric. For., 37, 545-554.

Chabot, R., Anton, H. and Cescas, M.P. (1996) Growth promotion of maize and lettuce by phosphate solubilizing Rhizobium leguminosarum biovar. phaseoli. Plant and Soil, 184, 311-321.

Chung, H., Park, M., Madhaiyan, M., Seshadri, S., Song, J., Cho, H. and Sa, T. (2005) Isolation and characterization of phosphate solubilizing bacteria from the rhizosphere of crop plants of Korea. Soil Biol. Biochem., 37, 1970-1974.

Coutinho, F.P., Felix, W.P. and Yano-Melo, A.M. (2012) Solubilization of phosphates in vitro by Aspergillus spp. and Penicillium spp. Ecol. Eng. 42, 85-89.

El-Afry, M.M., El-Nady, M.F. Belal E.B.A. and Metwaly, M.M.S. (2012) Physiological responses of drought stressed wheat plants (triticumaestivum L.) treating with some bacterial endophytes. $J$. Plant Production, Mansoura Univ., 3 (7), 20692089.

El-Gamal, A.M. (1996) Response of potatoes to phosphorous fertilizer levels and phosphorene biofertilizer in the newly reclaimed areas. Assiut Journal Agriculture Science, 27 (2), 77-87.

Fankem, H., Laurette, N.N., Annette, D., John, Q., Wolfgang, M., François-Xavier, E. and Dieudonné, N. (2008) Solubilization of inorganic phosphates and plant growth promotion by strains of Pseudomonasfluorescens isolated from acidic soils of Cameroon. African Journal of Microbiology Research, 2, 171-178.

Gulati, A., Sharma, N., Vyas, P., Sood, S., Rahi, P., Pathania, V. and Prasad, R. (2010) Organic acid production and plant growth promotion as a function of phosphate solubilization by Acinetobacter rhizosphaerae strain BIHB 723 isolated from the cold deserts of the trans-Himalayas. Arch. Microbiol., 192, 975-983.

Gyaneshwar, P., Kumar, G.N., Parekh, L.J. and 
Poole, P.S. (2002) Role of soil microorganisms in improving p nutrition of plants. Plant Soil., 245, 83-93.

Hashmi, Z.H., Khan, M.J., Akhtar, M., Sarwar, T. and Khan, M.J. (2016) Enhancing phosphorus uptake and yield of wheat with phosphoric acid application in calcareous soil. J. Sci. Food Agric. DOI 10.1002/ jsfa.7921.

Hilali, A., Przvost, D., Broughton, W.J. and Antoun, H. (2000) Potential use of Rhizobium leguminosarumbv. trifolii as plant growth promoting rhizobacteria with wheat abstract. $17^{\text {th }}$ North American Conference on Symbiotic Nitrogen Fixation, Laval University, Quebec, Canada23-28 July 2000.k

Holloway, R.E., Birtland, I., Frishke, D.M., Mclaughin, M.J. and Shepperd, W. (2001) Improving fertilizer efficiency on calcareous and alkaline soils with fluid sources of P, N and Zn. Plant Soi., 236, 209219.

Illmer, P. and Schineer, F. (1992) Solubilization of insoluble phosphates by microorganisms isolated from forest soils. Soil Biol. Biochem., 24, 389-395.

Jena, S.K. and Rath, C.C. (2013) Optimization of culture conditions of phosphate solubilizing activity of bacterial sp. isolated from Similipal biosphere reserve in solid-state cultivation by response surface methodology. Int. J. Curr. Microbiol. App. Sci., 2 (5), 47-59.

Kampfera, P., Ruppel, S. and Remus, R. (2005) Enterobacter radicincitans $\mathrm{sp}$. nov., a plant growth promoting species of the family Enterobacteriacea. Systematic and Applied Microbiology, 28, 213-221

Khalid, A., Arshad, M., Zahir, Z.A. and Khaliq, A. (1997) Potential of plant growth promoting rhizobacteria for enhancing wheat yield. J. Anim. Plant Sci., 7, 53-6.

Khan, M.S., Zaidi, A., Ahemad, M., Oves, M. and Wani, P.A. (2010) Plant growth promotion by phosphate solubilizing fungi-current perspective. Arch. Agron. Soil Sci. 56, 73-98.

Kmecl, V., Sudin, J. and Zupancic-Kralj, L. (2005) Validation of analytical methods used for determination of nitrate in soil. Accred. Qual. Assur. 10, 172-176.

Krieg, N.R. and Holt, J.G. (1984) Bergey's Manual of Systematic Bacteriology, 1: 694. Williams and Wilkins, Baltimore, MD, USA.
Kumar, V., Behl, R.K. and Narula, N. (2001) Establishment of phosphate-solubilizing strains of Azotobacterchroococcumin the rhizosphere and their effect on wheat cultivarsunder greenhouse conditions. Microbiol. Res., 156, 87-93.

Leggett, M.E., Gleddie, S.C. and Holloway, G. (2001) Phosphate-solubilizing microorganisms and their use. In: Plant Nutrient Acquisition, Ae, N. et al. (Ed.) pp. 299-318.New perspectives. SpringVerlag, Tokyo.

Mardad, I., Serrano, A. and Soukri, A. (2014) Effect of carbon, nitrogen sources and abiotic stress on phosphate solubilization by bacterial strains isolated from a Moroccan rock phosphate deposit. J. of Adv. Chem. Eng. 1,102. doi:10.4172/20904568.1000102

Mehnaz, S., Kowalik, T., Reynolds, B. and Lazarovits, G. (2010) Growth promoting effects of corn (Zea mays) bacterial isolates under green house and field conditions. Soil Biol. Biochem. 42, 1848-1856.

Mehrvarz, S., Chaichi, M.R. and Alikhani, H.A. (2008) Effects of phosphate solubilizing microorganisms and phosphorus chemical fertilizer on yield and yield components of barely (Hordeum vulgare L.). Am-Euras. J. Agric. Environ. Sci., 3, 822-828.

Minaxi, Saxena, J., Chandra, S. and Nain, L. (2013) Synergistic effect of phosphate solubilizing rhizobacteria and arbuscular mycorrhiza on growth and yield of wheat plants. Journal of Soil Science and Plant Nutrition, 13 (2), 511-525.

Montanez, A., Blanco, A.R. Barlocco, C., Beracochea, M. and Sicardi, M. (2012) Characterization of cultivable putative endophytic plant growth promoting bacteria associated with maize cultivars (Zea mays L.) and their inoculation effects in vitro. Appl. Soil Ecol. 58, 21-28

Moran, R. and Porath, D. (1980) Chlorophyll determination in intact tissues using N, N-Dimethyl formamide. Plant Physiol. 69, 1370-1381.

Muller, J. (1991) Determining leaf surface leaf area by mean of linear measurements in wheat and tritical (brief report). Archiv Fuchtungsforsch, 21 (2), 121 - 123. [PI. Br. Absts. 63 (5), 4811, 1993]

Naeem, A., Akhtar, M. and Ahmad, W. (2013) Optimizing available phosphorus in calcareous soils fertilized with diammonium phosphate and phosphoric acid using Freundlich adsorption isotherm. Sci. World J. Article, ID 680257. 
Naik, P.R., Raman, G., Narayanan, K.B. and Sakthivel, N. (2008) Assessment of genetic and functional diversity of phosphate solubilizing fluorescent pseudomonads strain from rhizospheric soil. B.M.C. Microbiology, 8- 230.

Nopparat, C., Jatupornpipat, M. and Rittiboon, A. (2008) Screening for phosphate solubilizing bacteria and optimum of bacterial cultivation by response surface methodology. Kmitl Sci. J., 8 (2) (Section A)

Panhwar, Q.A., Radziah, O., Zaharah, A.R., Sariah, M. and Razi, I.M. (2011) Role of phosphate solubilizing bacteria on rock phosphate solubility and growth of aerobic rice. J. Environ. Biol., 32, 607-612.

Ramesh, A., Sharma, S.K., Sharma, M.P., Yadav, N. and Joshi, O. (2014) Plant growth-promoting traits in Enterobacter cloacae subsp. dissolvens mdsr 9 isolated from soybean rhizosphere and its impact on growth and nutrition of soybean and wheat upon inoculation. Agric. Res., 3 (1), 53-66.

Saber, K., Nahla, L.D. and Chedly, A. (2005) Effect of $\mathrm{P}$ on nodule formation and $\mathrm{N}$ fixation in bean. Agron Sustain Develop., 25, 389-393. doi: 10.1051/ agro:2005034

Schoebitz, M., Ribaudo, C., Ciampi, L. and Poncelet, D. (2007) Plant growth promoting properties of a strain of Enterobacter ludwigiiisolated from Loliumperenne L. rhizosphere. XVth International Workshop on Bioencapsulation, Vienna. Au. Sept 6-8, 2007 p 4-3

Seshadri, S., Ignacimuthu, S. and Lakshminarsimhan, C. (2002) Variations of heterotrophic and Phosphate solubilizing bacteria from Chennai, southeast coast of India. Ind. J. Mar. Sci., 31 (1), 69-72.

Shoebitz, M., Ribaudo, C.M., Pardo, M.A., Cantore, M.L., Ciampi, L. and Cura, J.A. (2009) Plant growth promoting properties of a strain of Enterobacter ludwigii isolated from Loliumperenne rhizosphere. Soil Biol. Biochem. 41, 1768-1774.

Singh, H. and Reddy, M.S. (2011) Effect of inoculation with phosphate solubilizing fungus on growth and nutrient uptake of wheat and maize plants fertilized with rock phosphate in alkaline soils. Eur. J. Soil. Biol. 47, 30-34.

Singh, R.R. and Prasad, K. (2011). Effect of biofertilizers on growth and productivity wheat (Triticumaestivum L.). J. Farm. Sci. 1, 1-8.

Subba, R.N.S. (1993) "Biofertilizeres in Agriculture and Forestry", $3^{\text {rd }}$ ed., Oxford and IBH Publishing Co. Pvt.
LTD., New Delhi. pp.129-135.

Vahed, H.S., Shahinrokhsar, P. and Heydarnezhad, F. (2012) Performance of phosphate solubilizing bacteria for improving growth and yield of rice (Oryza sativa L.) in the presence of phosphorus fertilizer. Intl. J. Agri. Crop Sci., 4 (17), 1228-1232.

Wakelin, S., Warren, R., Harvey, P. and Ryder, M. (2004) Phosphate solubilization by Penicillium spp. closely associated with wheat roots. Biol. Fert. Soils., 40, 36-43.

Walpola, B.C. and Arunakumara, K.K.I.U. (2015) Assessment of phosphate solubilization and indole acetic acid production in plant growth promoting bacteria isolated from greenhouse soils of Gonju-gun, south Korea. Tropical Agricultural Research \& Extension, 18(1), pp.31-39. DOI:http://doi.org/10.4038/tare. v18i1.5322

Whitelaw, M.A. (2000) Growth promotion of plants inoculated with phosphate solubilizing fungi. $A d v$. Agron., 69, 99-151.

Xiao, C.Q., Chi, R.A., Li, X.H., Xia, M. and Xia, Z.W. (2011) Biosolubilization of rock phosphate by three stress-tolerant fungal strains. Appl. Biochem. Biotechnol., $165,719-727$

Yadav, J., Verma, J.P., Yadav, S.K. and Tiwari, K.N. (2010) Effect of salt concentration and $\mathrm{pH}$ on soil inhabiting fungus Penicillium citrinum Thom for solubilization of Tricalcium phosphate. Microbial. J. 1, 1-7.

Zafar-ul-Hye, M., Zahir, Z.A., Shahzad, S.M., Naveed, M., Arshad, M. and Khalid, M. (2007) Preliminary screening of rhizobacteria containing ACC deaminase for promoting growth of lentil seedlings under axenic condition. Pakistan Journal of Botany, 39, 1725-1738.

Zaidi, A., Khan, M.S., Ahemad, M. and Oves, M. (2009) Plant growth promotion by phosphate solubilizing bacteria. Acta Microbiol. Immunol. Hungarica, 56, 263284. 